This item was submitted to Loughborough's Research Repository by the author.

Items in Figshare are protected by copyright, with all rights reserved, unless otherwise indicated.

\title{
You have to try your luck: male Ghanaian youth and the uncertainty of football migration
}

\section{PLEASE CITE THE PUBLISHED VERSION}

http://dx.doi.org/10.1177/0308518X15594920

\section{PUBLISHER}

(C) Pion

\section{VERSION}

AM (Accepted Manuscript)

\section{PUBLISHER STATEMENT}

This work is made available according to the conditions of the Creative Commons Attribution-NonCommercialNoDerivatives 4.0 International (CC BY-NC-ND 4.0) licence. Full details of this licence are available at: https://creativecommons.org/licenses/by-nc-nd/4.0/

\section{LICENCE}

CC BY-NC-ND 4.0

\section{REPOSITORY RECORD}

Esson, James. 2019. "You Have to Try Your Luck: Male Ghanaian Youth and the Uncertainty of Football Migration”. figshare. https://hdl.handle.net/2134/17415. 
Esson, James. In Press. You have to try your luck: male Ghanaian youth and the uncertainty of football migration. Environment and Planning A.

Version: Accepted for publication

Please cite published version 


\section{Abstract}

The migration of male African youth within the football industry, particularly cases involving human trafficking, has become a subject of academic and political interest. This article contributes to work on this topic and to literature on the agency of youth in the urban Global South by turning the academic gaze away from European actors and settings, and towards their African counterparts. Drawing upon research conducted in Ghana, the article reveals how youth perceive migration through football as a solution to the socio-economic uncertainty and life constraints facing them in neoliberal Accra. This perception is tied to broader representations of spatial mobility as a precursor for social mobility. Youth attempt to achieve spatial mobility through football by 'trying their luck', a form of social navigation that is used to mediate the uncertainty associated with this strategy for realizing spatial change. Through illustrating why youth want to be spatially mobile and how they attempt to do so through football, this article demonstrates why studies of African football migration need to engage better with how conditions inside the football industry interact with those beyond it.

\section{Keywords}

Accra, football migration, Ghana, urban, youth

\section{Acknowledgments}

The ESRC (ES/H011234/1) and UCL funded this doctoral research. I would like to express my gratitude to all of the participants associated with the three clubs in Accra where I conducted my fieldwork. I am also grateful to staff at the GFA, GHALCA, PFPAG and the Vodafone Right to Dream Academy for their assistance. Many thanks also to JoAnn McGregor, Ben Page, Kate Gough and the three anonymous referees for their constructive comments and suggestions. 


\subsection{Introduction}

African footballers have become a staple of professional European Leagues (Alegi, 2010). As noted by Darby et al. (2007) and Poli (2010b), the growing presence of young West African footballers plying their trade in Europe has given rise to accusations of exploitative neo-colonial relations between core and peripheral footballing regions. European clubs are argued to use their economic clout to shape the labour migration process and dictate trade on terms benefitting the European football (core) at the detriment of their African counterparts (periphery). As a result, research on the migration of African football players usually focuses on the practices of European institutions and is viewed from a European perspective. Recent work by Carter (2013) and Darby (2013) has attempted to counter this trend, by offering new theoretical perspectives on the migration of African football players using actor network theory and global value chains respectively. Meanwhile Poli (2010a) has highlighted the growing presence of African players in Asia and the Middle East. Nevertheless, a Eurocentric structural theoretical lens remains in vogue because it can illustrate, albeit in broad brushstrokes, a general picture of player movement within the professional football industry. Alongside this research on football labour migration studies have emerged focusing on the issue of football related human trafficking (Donnelly and Petherick, 2004; Esson, 2015, Poli, 2010b). In short, this is where after handing over money to individuals claiming to be certified football agents, the player is promised a playing contract or trial with a foreign club. In some cases, the alleged interest from a professional club is often bogus, and the agent abandons the player upon arrival in the destination country. In other cases, a contract is in place but it is of an exploitative nature. Although entailing two rather different migratory processes, attempts to understand African football labour migration and human trafficking through football suffer from a common shortcoming. The agency of African actors and broader understandings of the young people involved are usually conspicuous by their absence (Esson, 2015; van der Meij and Darby, 2014). Consequently, many of the conclusions put forward by analysts and commentators concerned with African football migration are inadvertently reductive. 
In this article, I argue that studies of African football migration need to engage better with African contexts, particularly the way structures and conditions within the football industry interact with those beyond it. I use Ghana, one of the continents top five exporters of footballing talent (Darby, 2013), as a case study to demonstrate this point and provide a more nuanced understanding of the migration processes mentioned above. I situate the article within research on the agency of young people in the urban Global South, and work exploring how people in sub-Saharan Africa increasingly view spatial mobility as a precursor for social mobility. My reason for doing so is because while academic literature often associates African football migration with children and youth, these discussions are rarely brought into conversation with contemporary research on young people. Likewise, the desire to migrate is often attributed to structural forces within the football industry, and little attention is paid to how this could be linked to conditions beyond it, such as broader cultural meanings of spatial mobility percolating within society.

The article draws on data collected in Accra in 2011 during several months of fieldwork, which entailed multi-sited ethnography at three amateur neighbourhood football clubs with youth academies (under 12, 14 and 17), referred to here as Austin
Texans FC, Barracks FC and Future Icons FC. All three clubs had over 100 registered players, and two senior teams. I attended 116 training sessions across the three clubs as well as home and away matches. Alongside participant observation, I conducted 211 informal interviews with players in order to gain basic demographic information about participants and their thoughts on football and life in Ghana. This involved talking to 2 or 3 players on a one to one basis before or immediately after training for 10-20 minutes, with details for each club recorded in a research diary. The interviews were informal in nature because although they were based around identified themes, due to the age of many of the participants they were more conversational than formal in nature. These interviews were complimented by 20 formal semistructured interviews with senior team players, coaches and club owners. These interviews were audiotaped and lasted between 60-120 minutes. In addition to the data collected at the amateur clubs, I also spent time and conducted 10 expert interviews at two Premier League football clubs, the Ghanaian Football Association Regional office in Accra, the Ghana League Cubs Association, the Professional Footballers Association of Ghana and the Right to Dream Football Academy.

The first half of the article depicts the context in which young Ghanaian footballers ply their trade, 
and draws attention to how aspirations to migrate and enact spatial change are linked to their engagement with structures within and beyond the football industry. I then examine how increased competition from other would-be footballers, and the difficulty of distinguishing legitimate chances to migrate from fraudulent ones, makes obtaining a transfer and migrating through football an uncertain course of action. The second half of the article builds on literature concerning social navigation, causality in urban sub-Saharan Africa, and the racial signification of sport to illustrate how the solution to the uncertainty surrounding football migration is to "try your luck'.

\subsection{The quest to play outside}

Since the mid 1980's through to the present-day, the dissolution of liberal welfare policies by various Ghanaian governments has been reasonably consistent (Obeng-Odoom, 2013). In Ghana, this ideological shift has produced a form of subjectivity whereby an individual is obliged to take greater responsibility for their future (Langevang and Gough, 2009). These changes have eroded the belief that individuals reside within extended communities and, more recently, the post-independence era of President Kwame Nkrumah's social developmentalism that actively promoted the idea that the state should assist in welfare provision. This new idea of individual responsibility has a history and it is a history closely associated with the suite of ideas usually bracketed together under the banner of neoliberalism.

At a macro level, Ghana has had a relatively successful decade with economic growth rates of between 5-11\% (Obeng-Odom, 2013). Yet much of this growth is tied to the recent discovery of oil and gas, and as noted by Darkwa (2013) three decades of neoliberal reform has led to a decline in formal sector jobs. This has created a scenario whereby the informal sector, which is estimated to form approximately $80 \%$ of the economy, dominates the employment landscape (Obeng-Odom, 2013). In a previous article, I showed how the attraction of a career in football among male Ghanaian youth emerges through an engagement with these broader structural changes taking place within Ghanaian society (Esson, 2013), which encourages young people to be job creators not job seekers (see also Langevang and Gough, 2012). The perception that a career in football offers a means to generate an income and be self-sufficient has emerged in this context where young and old alike are frequently tasked with ensuring their own financial wellbeing without the mattress of state welfare provision to fall back on.

Tom Vernon, a former scout for Manchester United and founder of the Right to Dream Academy 
(RTD), highlighted the issue of increasing numbers of young Ghanaians seeking to attain a career in football during a discussion about the selection process for a place at the academy. The RTD academy, which is a non-profit organization registered in Ghana, the UK and USA, is renowned for its excellent facilities and educational and vocational training schemes. Successful applicants are offered a five-year scholarship and intake is normally from age ten upwards. With regards to life prospects after leaving the academy, 23 former residents are currently at international universities, colleges and boarding schools, two have signed professional contracts in the North American MLS, and the English Premier League side Manchester City have signed five players in the past three years (see also Darby, 2013). For the 2011 selection process, which consisted of three main rounds and tournaments staged in various locations around the country, 18,000 hopefuls attended trials for 15 places.

The growing popularity of football among young Ghanaians is also reflected in broader changes taking place in amateur youth football or, as it is colloquially known in Ghana, 'Colts' (under 12, 14 and 17). In March 2011 while registration was still taking place for a new regulated and national Colts league, the GFA regional office in Accra used their registration database to estimate that seven hundred clubs in twelve regional zones would take part. Two hundred and forty of these clubs were located in Accra spread over eleven districts, with an estimated 25,000 players registered. These figures constitute an almost threefold increase when compared to the previous decade and there is concern that this growth is unsustainable, for example in relation to provision of referees and pitches.

In addition to the reasons mentioned above, a key reason why a career in football is particularly appealing to male Ghanaian youth is because football is associated with material wealth through mobility. Kurt Okraku, secretary of the Ghana League Clubs Association (GHALCA) articulated this point when he described the zeitgeist of Ghanaian football as follows;

"You will find that every player has the mentality that they want to play outside of Ghana that is the first and biggest thing. Whether they can go and perform that is another issue all together, but the belief is that they must play outside of Ghana. They want to go and make money, they want to come back and drive around in the flashy cars"

The previous quote succinctly articulates an important point when attempting to understand contemporary Ghanaian football. There is an 
overwhelming impression that migration to a professional football league, ideally outside of Africa, constitutes the best way to lift an individual and therefore vicariously their family out of poverty (see also van der Meij and Darby, 2014). This belief that migration will lead to improved life chances is not unique to aspirant footballers. It is a facet of broader cultural representations of mobility circulating in society, which has also been highlighted in nonfootball related research with Ghanaian youth (Coe, 2012; Ungruhe, 2010). Yet while studies have found that the majority of migration takes places within Africa itself (Bakewell and De Haas, 2007), this is often perceived by Ghanaian youth as being less advantageous than migration to Europe and the US, which are associated with opportunities for the accumulation of material wealth and attainment of economic security (Langevang, 2008). To some extent, this is also true about the state of play in professional football where despite visible signs of improvement, most notably in South Africa, most sub-Saharan African leagues are generally not as lucrative or well developed as their European equivalents (Darby and Solberg, 2010). Abdullah, a twenty-year-old senior team player at Austin Texans FC, expressed this point when he noted;
"If you say you want to be a footballer and you play locally, just think, even in the Premier League how many teams have a gym? Here you don't even eat properly before a match or training. That's why you have to move to where you know things are different"

Anthony Baffoe, a former Ghanaian international football player and the current secretary of the Professional Footballers Association of Ghana (PFAG), provided further insights as to why those plying their trade in Ghanaian football are keen to play outside. Firstly, the average monthly salary for professional football players in Ghana is relatively low, particularly when compared to players at elite European clubs. For example, a handful of players in the English Premier League are known to earn upwards of $£ 250,000$ per week, whereas in Ghana monthly salaries range from $50 \mathrm{GHC}$ to $500 \mathrm{GHC}^{1}$, with the vast majority of players earning less than $200 \mathrm{GHC}$ if they are paid at all. Moreover notwithstanding the best efforts of the PFAG, the industry is rife with contractual insecurity and, in accordance with a neoliberal ethos, health care provision and the risks associated with a football career such as debilitating injury and early retirement with no guarantee of a

\footnotetext{
1 Ghana's currency is the Cedi. In 2011 when I conducted my fieldwork $f 1 \mathrm{GBP}=2.5 \mathrm{GHC}$
} 
pension are often borne by the individual. Anthony Baffoe went on to explain how this situation was fuelling migration, including to countries not traditionally known for their footballing infrastructure;

"There are young [Ghanaian] players playing in India and Bangladesh and Pakistan. It sounds crazy like I am exaggerating? You can't say that it is because they play a higher standard of football there than here. You see? It is just because they are able to pay the players a certain amount of money"

Anthony Baffoe's observation is particularly prescient in light of events that took place later that year. In the summer of 2011, an article in The Daily Guide Accra newspaper and website reported that an estimated 70 Ghanaians were scammed into thinking they had trials at football clubs in Mauritius (Coe and Wiser, 2011). While in Accra I saw for myself how young Ghanaian males' desire to use football as a means to generate an income and help their families financially, alongside their family's zeal for them to do so, can be problematic. For example, the under-17 team at Barracks FC were led to believe that a talent scout working for FC Juventus (Serie A in Italy) had come to watch them play, and for a fee could arrange trials for players. The head coach was skeptical, and this skepticism was justified when FC Juventus confirmed the 'talent scout' did not work for them. Nevertheless, players told me that despite the head coach openly declaring his suspicion about the intermediaries' authenticity, their families placed considerable pressure on them to just pay the talent scout whatever was necessary to secure a trial abroad.

Thus through my interactions with young people at the three clubs and high profile cases in the media, I was not only reminded of Messner's (1989) seminal research in the US, where he highlighted how social institutions and families serve to systematically channel disproportionately large numbers of young black men into a career in sport. It also became increasingly apparent that having opted to pursue a career in professional football, the players I encountered now found themselves in somewhat of a quandary. Migrating through football when potentially competing against over 20,000 players in Accra alone with the same dream is difficult enough. But this task becomes even trickier when attempted in a footballing climate that is shrouded in uncertainty.

\subsection{Justifying your inclusion in an uncertain industry}

Encounters with fake talent scouts did not happen every day, but it was one of several examples of 
Ghanaian football's uncertain nature. This uncertainty often took more subtle forms. For example, dogs and goats running onto the field and sabotaging a goal scoring opportunity; pitches being double booked; a shortage of match officials; being called up to represent the national youth team and then being turned away from the training camp for no apparent reason; and travelling two hours for an away fixture without knowing who the opponents are.

It is from this uncertain and unpredictable landscape that knowledge and understanding of the football migration process stems. This knowledge is fluid and transferable in the sense that people are the carriers. It is learnt and subsequently reproduced via the insights gained living in this particular football milieu and witnessing others leave. Be they high profile transfers recounted in the media, more proximate cases or word of mouth. The young people at the clubs were also acutely aware that the act of football migration emerges from and through the practices of a multitude of actors, ranging from the players themselves to parents, teachers, clubs, football associations, managers and recruitment agents.

As indicated in the above examples, it can be difficult for players to distinguish legitimate opportunities from illusions concocted by opportunistic fraudsters, who might be trying to profit

from human trafficking through football. Human trafficking through football is an irregular form of migration in that it involves 'people moved by migrant smugglers or human trafficking' (Koser 2010, p.183). This would suggest that a 'regular form' of football migration must exist, yet as highlighted by Poli (2010a), football related migrants do not follow a default predefined path, thus making it difficult to outline an archetypal migration trajectory. However, what clearly distinguishes 'regular' football migration from its 'irregular' counterpart is that in the case of the former, migration complies with regulations outlined by the International Federation of Association Football (FIFA). Therefore 'regular' football migration is directly linked to recruitment between two clubs registered with their national associations, involves a certified agent or lawyer, and players enter a destination country legally (Esson, 2015).

African football migrants will typically begin by playing for a local neighbourhood team or youth academy (under $17 \mathrm{~s}$ ), then progress to a senior amateur or professional side. Migration can potentially take place at any of these stages but on average, African players move abroad when they are nineteen years old (Poli, 2010a). The issue of duplicitous agents is less problematic for young players at an established academy like RTD, which 
regularly deals directly with high profile registered clubs and agents in accordance with FIFA's transfer system. However, for players at clubs in the Colts leagues with less familiarity with the official transfer system, football agents and talent scouts are strongly linked to trials known in short as a 'Justify', and in full as a 'Justify your inclusion'. GFA executive Herbert Adika describes a 'Justify' as follows;

"It is happening oh it is happening all over Ghana right now. If this pitch could talk it would tell you right now how many agents have come here to do what they call justify your inclusion. They say you will be travelling to let's say any European country just come and pay 3,000 cedis. You will see people rushing to pay for a trip but they don't even know if it will come off'

Accordingly, the players and staff at all three clubs strongly associated a 'Justify' and foreign intermediaries, who in most cases they would be meeting for the first time, with career progression and the ability to migrate. However one of the problems with a 'Justify', aside from the potential to be scammed, is that it is a highly reactive way to procure an opportunity to migrate. Godwin, a seventeen year old trying to make the step up to Barracks FC' senior team, provided an interesting example of how to be proactive and create an opportunity to migrate through football.

During what appeared to be a routine early morning training session I was informed that Godwin had been offered a contract by a professional Chinese team. This was particularly intriguing as I was certain he had not mentioned attending a trial in any of our recent conversations. It transpired that Godwin had not met the scout on a football pitch in Accra, rather he had met him online in an Internet café. He had uploaded a CV detailing his football biography and a video (recorded using his mobile phone) displaying his skills to a football recruitment website. Godwin believed the site used by professional clubs and licensed agents to find players. An agent claiming to have seen his profile online then contacted him on a popular social networking site. After exchanging a handful of emails, the agent offered Godwin a contract with a professional Chinese football team worth \$400,000USD per season for three years, subject to Godwin obtaining a visa and paying a finders fee so the agent could ratify the deal.

This was the first time I had personally come across a case where the mobilization of football migrants had taken place online, despite an emerging literature on Ghanaian youth and their use of information communication technology (see Burrell, 2012). More importantly, I was cynical about a 
professional football club offering someone a multimillion-dollar contract based on footage taken on a mobile phone. Godwin was told that in order to secure a visa he would need to provide proof that he was a footballer. It was during his attempts to sort out travel documents and his player registration that the agent was found to be a fraudster. The 'agents' tactic involved contacting athletes, coaches and physiotherapists, and offering them contracts with major sporting institutions in exchange for his finder's fee. Godwin was glad that he had been made aware of the scam before handing over any money but he was simultaneously disappointed that his dream of a professional contract was no longer a reality. Nevertheless, this experience did not deter Godwin from continuing to look for transfer opportunities online.

The previous quotes and anecdote draw attention to an important yet under considered question, namely, how do young aspiring footballers make sense of risk and uncertainty in relation to migration opportunities? The concept of risk has been explored in the social sciences most notably in the work of Giddens (1991) and Beck (1992). However, like Hernández-Carretero and Carling (2012), I propose that while there is often an implicit recognition that risk entails multiple meanings and uses according to the context, in contemporary
Western vernacular risk is often imbued with negative connotations and synonymous with danger.

In order to understand the actions of youth trying to migrate through football, a more valueneutral interpretation of risk and uncertainty is needed for two key reasons. Firstly, at a more general level and tied to discussions at the start of this section, scholars of African urbanism have drawn attention to how the abandonment of the nationalist development project in contexts dominated by neoliberal governance has resulted in the imbrication of risk within the everyday practices of many urban residents (Pieterse, 2011). Secondly, and more directly linked to the topic at hand, when I attempted to understand agency and risk in relation to how the youth I encountered sought to migrate through football, and assessed whom to leave with amidst a context of unpredictability and uncertainty, the answer to this question was simple: 'You have to try your luck'.

'Trying your luck' was an expression used by the players to communicate a frame of mind, temperament and associated forms of practices to help surmount the uncertainty associated with life in contemporary Accra. It is connected to the popular Ghanaian notion of 'managing' (Langevang, 2008), and resonates with 'dubriagem' in Guinea Bissau (Vigh, 2009) and 'débrouiller' in Cameroon (Waage, 
2006). These expressions are used by young people in their respective countries to describe the ability to improvise using accessible resources, and amend strategies and plans according to opportunities and constraints (see also Honwana and de Boeck, 2005). This form of conduct is termed 'social navigation', a type of youthful agency that entails attempting to make calculated decisions and behaving in a judicious manner despite often lacking the privilege of being able to base these calculations on discrete and stable variables (Langevang and Gough, 2009). The term draws on de Certeau's (2011) distinction between 'tactics' and 'strategies', which allows the tactical practices that emanate from actors' creative responses to their surroundings to be understood as a form of strategic navigation (Van Blerk, 2013; Vigh, 2009).

Langevang and Gough, in their research documenting how mobility has become essential to the strategies used by young Ghanaians trying to navigate socioeconomic uncertainty, demonstrate how 'a social navigation perspective provides a means of illuminating 'how youth are able to move, what they seek to move towards and the ways external forces seek to shape their movements' (Christiansen et al. 2006 cited in Langevang and Gough, 2009 p. 743). They also provide insights on the bounded nature of mobility within the city. However, the concept of social navigation is primarily viewed in relation to daily movement through the urban landscape as part of young people's livelihood strategies.

In the discussion that follows, instead of focusing on the strategies young people employ as part of their movements to disparate parts of Accra, I use the notion of 'trying your luck' to turn our attention towards the strategies young people use as they attempt to migrate through football. Additionally, I aim to explore how migration-related risk-taking emerges within Ghanaian football.

\subsection{You have to try your luck}

Langevang astutely highlighted that in a society marked by economic hardship and neo-liberal reform, when Ghanaian youth say they are managing they are referring to practices that; 'include making a plan, but not necessarily implementing it, and the ability to adapt to the moment.... a delicate balancing act between keeping in line with long lasting ideals while at the same time being able to envision, accept and adopt new paths' (2008, p. 2046). During discussions with players about these ideas associated with managing in relation to their plans within and beyond football, they often stated that the ability to adapt and decide which course of action to take was a matter of acknowledging the prevailing socio- 
economic climate and then 'trying your luck'. This was

typically said in a nonchalant manner, implying to some extent that plans were made and then simply left to fate. However further probing revealed that this was not the case. Instead, 'trying your luck' signified a willingness to plan and act according to awareness that despite being made in uncertain contexts, their plans and actions had the potential to generate both beneficial and harmful outcomes, and that these outcomes tend to be influenced by how certain factors interact with opportunities and constraints.

The players explained that in Ghana a key factor in maximizing opportunities and overcoming constraints in moments of uncertainty is money. Money enables a person to sidestep almost any obstacle and unexpected situation they are likely to encounter. It is far easier 'trying your luck' with pockets loaded with cash. To some extent, this is also true of the football industry, as indicated above in the case of a 'justify your inclusion'. Alongside money two other factors were also considered vital, a discernible talent or skill and the spiritual realm. If used correctly these three factors were deemed to hold the key to successfully 'trying your luck', particularly in relation to longer term planning. Crucially, an advantage of 'trying your luck' and migrating through a career in professional football- unlike other areas of Ghanaian life - is that it is not primarily dependent on financial resources. This was particularly pertinent given that the majority of high profile Ghanaian footballers have historically come from low-income households (van der Meij and Darby, 2014). Money is important, but as Mo, a 17-year-old academy player at Future Icons FC explains below, a career in football is also dependent upon making the most of the other two factors mentioned above;

"The guys who are working because they can't play are jealous of us [footballers]. They want to be like us. But you see as we are standing here, plenty of people in Ghana can do something if you give them the ball, but Allah (God) has only truly blessed certain feet"

\subsection{Trying your luck and 'natural' skill}

As discussed above, a career in football is now viewed as a way to become spatially and socially mobile, and one of the key components of 'trying your luck' is the ability to harness a talent or skill. These two observations led me to try and understand an important and related point, namely why plenty of young Ghanaians feel that they can 'do something if you give them the ball'. In other words, why were the youth I met willing to try their luck through football? Although I have spent the majority of my life in England, I am a black Ghanaian by birth and 
parentage. This was perhaps why participants were quite forthright when explaining their reasons for trying to make use of their footballing ability as part of a strategy to improve their life chances by migrating through football. They openly espoused the idea that 'trying your luck' through football made sense because Ghanaians are racially predisposed to excel at football. For example, when I asked Daniel, a twentyyear-old senior team player and coach of the Future Icons FC under-17 team why Ghanaian youth believed they could become footballers, he replied as follows;

"You yourself you know, you know. Naturally we are strong we can play that's what we blacks think. Football is part of our spirit. Even me I think the same thing and that's why I am playing, that's why so many boys think they can become footballers"

Young Ghanaians are not the first to suggest that a link exists between race and athletic performance. Scholars have shown how deeply held beliefs about race have been asserted through the lens of sport for several decades. A body of literature has developed to examine this 'racial signification of sport' through engagement with cultural, feminist and post-colonial perspectives (Azzarito and Harrison Jr, 2008 Bale and Cronin, 2003; Carrington, 1998; St Louis, 2004). This literature argues that the proposed link between race and athletic ability is a fallacy, but it also acknowledges that widespread belief in this link shapes the outlook of actors throughout the sports world. In Ghana, players and coaches not only believed that Ghanaians are naturally gifted footballers, but that professional European clubs are actively trying to sign them for that reason. Ben, an eighteen-year-old goalkeeper who had recently graduated to the Austin Texans FC's senior team, articulated this point as follows;

"In Ghana, football is about physique and we Africans are naturally tough, that is why the European clubs are chasing us to sign. Essien for instance, naturally he has the heart to play football. They want Essien because they know he can do the job. When you go to the park in the evening you will see people will just run round the pitch many times. Some clubs in Ghana will even train three times, morning, afternoon and evening. Even in the heat we can do it because we already have it deep inside of us"

Drawing attention to the fact that young Ghanaians seeking to 'try their luck' and migrate through football were aware of and acted upon certain beliefs attributable to bodily differences is not a trivial point. Ideas about race, specifically how it becomes 'embodied, lived, and put into motion in 
everyday encounters (Nayak, 2010, p.2372)' plays an important but under acknowledged role in the football migration process. For example, as mentioned above it can be difficult for players to distinguish authentic opportunities to migrate from scams. Accordingly, players not only used ideas about race to make sense of what they are capable of, but also what they believed others are able to do and to help them decide whom to trust. The owner of Austin Texans FC explained this point as follows;

"These agents put a pinch of truth in a big lie and because these players are so desperate to leave their brains go blank. They don't even ask questions like why am I paying 5,000 now? I could get an office in Osu and make it look professional, go down to the beach and make some white friends and ask them to come and chill at my office. Players will see me moving with white people and think I am connected... "This guy he moves with white people oh, he is a big boy"! ... I will tell them "I have this deal in Germany we need to get a video of you and send it. Then when we do the video the club will send an invitation letter before I go to Dubai on business, but first you just need to make a down payment"

The above quote resonates with Swanton's observation about 'the multiple, contingent, and devious ways in which race takes form in, and gives shape to, encounters' (Swanton, 2010 p.2332), but it also does more than that. When read alongside the broader understandings of young Ghanaian footballers provided beforehand, the quote highlights how the desire to be spatially mobile and understandings of race can come together and potentially result in exploitation through football migration. This is important because it demonstrates how one person is potentially able to exercise and abuse power over another person, which is crucial to understanding the mobilization of potential irregular migrants (Anderson, 2007).

Researchers working with youth in Ghana and other West African contexts can probably envisage how the scenario depicted above could feasibly take place. Studies have highlighted that as European countries and the US tighten their immigration policies, accordingly the quest for facilitators to assist with migration intensifies among prospective migrants (Langevang, 2008; Nyamnjoh and Page, 2002). Young Ghanaians, like West African youth more generally, have come to strongly associate white people and those considered to have permanent residence in Europe or the US with the ability to facilitate entry to these countries. This is because spatial mobility involves the production or reproduction of similarities and difference, as the 
ones doing the moving or being moved tend to position themselves or be positioned (hierarchically) in relation to those they encounter (Nyamnjoh, 2013, p.654). For example, during my stay in Accra I received numerous requests from senior and under17 players for advice on visa applications and invitation letters. It was assumed that as I was born in Accra but now lived in the UK and was in possession of a 'Red Book' (UK Passport), I must be privy to the secret world of international mobility and its machinations, and thus able to aid their attempts to migrate.

The challenges associated with securing a visa to countries in the Global North, and the conflation of foreigners with opportunities to migrate, means that encounters with those claiming to have connections to desirable geographical regions takes on added significance. This is especially true when trying your luck' and attempting to migrate through football. Ebo, an under-17 goalkeeper at Barracks FC, provided an example of this point when recounting his experience at a trial where an official scout from a professional French club came to watch the team. He said, 'by the grace of God I played an almost perfect game, I played very very nice maybe the best game of my life'. After the game, the scout informed the team manager that Ebo had indeed performed brilliantly but, 'he was not looking for a goalkeeper so it didn't matter how well I played'. During a discussion with Ebo and several members of the Barracks FC under-17 youth team, the players explained that setbacks such as the one Ebo experienced are demoralizing, frustrating, and serve to painfully demonstrate the challenging and uncertain nature of trying to migrate through football. But these setbacks do not result in the pursuit of an alternative plan for their life course.

In some cases, would-be football migrants became strategic about their choice of playing position, opting to play as defensive midfielders, on the wings and as attacking forwards whenever possible due to the perception that foreign scouts are actively seeking these types of players. Additionally, it was also important to nurture one's 'natural' footballing ability to improve the prospect of catching a foreign talent scouts' eye. Understanding expectations about how talent scouts expected them to perform was considered key to young people's migratory aspirations. Owners, coaches and players at all three clubs stressed how vital it was that they learnt and applied training methods used by European clubs to compliment the player's natural sporting ability. The strategies used to gain this information ranged from watching training videos online, to establishing relationships with organizations in the sport for development industry that could provide coaches from Europe and North America. Yet as Ebo's 
case highlights performances on the pitch do not always correlate with desired outcomes off it. Therefore alongside nurturing and developing one's 'natural' skills, the uncertainties and risks associated with trying to migrate through football were also mediated through engagement with the spiritual realm.

\subsection{Trying your luck and the spiritual realm}

The vast majority of players' at all three clubs believed in the existence of supernatural forces that interact with the material world and determine life chances and everyday activities. This way of thinking is not unique to young Ghanaian footballers (see Parish 2000; Schatzberg, 2006), and while references to supernatural causality in an African context are sometimes interpreted as confirming stereotypes of primitivism and backwardness, this understanding of causality is often a reflection of adaptation to modernity which occurs throughout the contemporary world (Geschiere, 1998; Meyer, 1998). For example, scholars have highlighted how professional football is littered with references to spiritual and religious causation (Armstrong and Giulianotti, 2004). In the UK, the 'Pray for Muamba' campaign after the Bolton Wanderers FC player Fabrice Muamba suffered a cardiac arrest during a televised match provides a high profile illustration of this point (Brown, 2012). Kurt Okraku, secretary of GHALCA, also touched on the prevalence of spiritual causality in the football industry as follows;

"The European will tell you that fasting before a game will affect the energy levels of a player. An African player will tell you to fuck off you are lying! Africans believe that luck plays a bigger role than the round leather itself. In our part of the world religion plays a big part, for Europeans maybe not a big part but it does play a part make no mistake about it. I have been to European clubs where religion is key... but most of these things do not come into the public domain"

In the context of Ghanaian football, the spiritual realm provided youth attempting to 'try their luck' through football with an explanatory tool to decipher events that appeared inexplicable or random. Such as playing the game of your life in front of a legitimate talent scout for a professional team, only to discover he is not looking for players in your position. Kojo, an under-17 player at Future Icons FC, provided another example of this when he compared the career of Michael Essien to his former international teammate Ishmael Addo. At the time, Essien was playing for Chelsea FC while Addo, who had spent most of his career at Accra Hearts of Oak, 
was playing for Wassaman United in the Ghanaian Glo Premier League.

"If you look at Michael Essien he was not the best player in the Black Satellites (Ghana under-20). Ishmael Addo was top goal scorer and was the star.

So Essien is doing or gaining something from the spiritual side that Addo isn't, or maybe Addo is doing something that he shouldn't be, which is affecting his spiritual support. Without spiritual backing you will never succeed"

As Kojo indicates above, in addition to helping make sense of situations and outcomes there was also a perception that the spiritual realm can be used to help determine them. Accordingly, players performed rituals and adopted spiritual practices in order to grease the palms of fate and attain a sense of control in a football industry that is marked by hardship, competition, individuation and uncertainty. The notable methods were praying, fasting and the use of what was colloquially known as 'medicine'. A term used to describe substances or objects believed to have apotropaic powers.

I discretely asked the players to describe precisely how they attempted to acquire spiritual support, i.e. their rituals and medicine of choice, yet I stopped doing so once it was explained that the components of one's medicine is not something to be shared or disclosed publicly. I did however inadvertently become embroiled in an altercation regarding the use of medicine at Barracks FC while talking to a player named Elias. Elias was unable to train with his under-17 teammates due to a hamstring injury and, during the course of our conversation he put on a pair of goalkeeping gloves that were lying amongst a pile of other equipment. Moments later Jonathan, the owner of the gloves, approached us and began remonstrating with Elias for placing his hands inside them. He warned Elias never to do so again because he could have altered the medicine's effectiveness and thereby harmed Jonathan's performances on the pitch.

Other examples of the recourse to spiritual causality included: players making the sign of the cross as they came onto the pitch, kissing a crucifix before a game, pointing to the sky and or prostrating on the ground to acknowledge God after scoring a goal, and pouring water that had been blessed by a priest over their heads before a match. It was also customary for teams to pray together before, during (at the half-time interval) and after the game. The team's 'prayer warrior', i.e. the person elected to take a lead role in imparting spiritual guidance to teammates, usually led the group prayer sessions. These practices and references to the spiritual world 
were prevalent across all three clubs, however Barracks FC's senior teams' five game losing streak provided an example of how practices varied according to circumstances.

In an attempt to improve results on the pitch, the players at Barracks FC lengthened their fasts and kept longer vigils before matches. This was alongside the standard requirement for players to attend the local Pentecostal church on Sunday, Monday, Wednesday and Friday evenings. Players at Future Icons FC were aware of the situation at Barracks FC, as their senior teams previously played in the same division, and many of the players were not surprised by the losing streak. Kwabena, a senior team player at Future Icons FC, explained that while spiritual support was important, Barracks FC had courted controversy the previous season when they released key players for not attending church;

"They (Barracks FC) had a striker and he scored for them in the lower divisions, now he is playing in Division One. In the middle of the league season they sacked him because he didn't go to church... they even sacked all of their defenders because of this church business. God bless them if they don't lose all the twenty-two games...For us we are not under any church and we have Muslims in our team so going to church is not compulsory... [but] for me I can't say that people put too much faith in luck and the church because it does help, but alone it is not enough"

As Kwabena indicates there is awareness that spiritual support alone is not enough to succeed in football. Similarly, Jonathan confronted Elias for potentially affecting his spiritual support, but he did so at a training session. Meanwhile players, staff and club owners do not just sit in church praying all day and night, they also use coaching methods to improve their chances of facilitating migration through football. All three examples highlight what Meyer (1998) describes as the tension between striving for proprietorship of one's self and the notion that a person is largely operated through spiritual powers. The belief that outcomes are principally determined by the will of a higher entity or spiritual powers is significant when trying to understand why youth are willing to pursue what could be seen as risky migration opportunities. As noted by HernándezCarretero and Carling (2012), it makes little sense to think in terms of risk if one believes that deities ultimately predetermine life chances. Thus the question of whether these scouts that players and clubs are so keen to please are genuine intermediaries working for professional clubs, or fraudsters on the lookout for their next mark is not something these youth consider too deeply. Why? Because when you 
are attempting to migrate through football in Ghana, you have to 'try your luck'.

\subsection{Conclusion}

This article approached the migration of young West African footballers from a different empirical starting point than is typically found in research on this subject. Instead of placing interpretative weight on the agency of actors and clubs based in European destination countries, insights were obtained from a variety of actors within the Ghanaian football industry ranging from youth players in academies to members of the Ghanaian Football Association. The paper demonstrated how the migratory process is linked to the ways a football industry interacts with the wider society in which it resides. By foregrounding this link, the article was able to contribute to understandings of African football migration and research concerning the agency of youth residing in contemporary Ghana.

The growing popularity of a career in football among youth is tied to the framing of young Ghanaians as responsible for their employment prospects in a context where opportunities in the formal labour market are dwindling, and state welfare provision for the unemployed borders on the nonexistent. The belief that playing football offers a way to lift an individual and their family out of poverty, especially if one is able to migrate to a foreign league outside of Africa, has emerged from within this structural milieu. This latter point resonates with non-football related research on youth in Ghana and sub-Saharan Africa more generally (see Carling, 2002; Langevang, 2008), which has drawn attention to the pervasiveness of a migratory temperament.

Additionally, like the scholars mentioned above, the paper highlighted how aspirations to migrate, in this case through football, are underpinned by broader cultural meanings of mobility circulating in society. Problematically, in the context of Ghanaian football, the popularity of this aspiration has resulted in heightened competition for opportunities as increasing numbers of people attempt to use football as a means to gain passage abroad. Yet having opted to go down the football route, young Ghanaians not only found it difficult to create opportunities to migrate in the face of competition from others with similar intentions, they also faced the added challenge of trying to identify legitimate contract offers from those concocted by opportunistic fraudsters engaging in human trafficking through football. Players attempted to mediate the risks and potential pitfalls dotted across the Ghanaian footballing landscape by applying a form of social navigation known as 'trying your luck'. This entailed 
making use of a distinguishable talent or skill (in this case football) and the spiritual realm.

Previous research with Ghanaian youth used the concept of social navigation as a way to illuminate understandings of how daily mobility figures in young people's livelihood strategies (see Langevang and Gough, 2009). Engagement with the idea of 'trying your luck' within the context of Ghanaian football extended previous work on social navigation by shifting the temporal and spatial frame of reference, and highlighting the strategies used by youth in Accra. This paper revealed how the agency of young Ghanaian footballers is influenced by belief in supernatural causality, and understandings of race and bodily difference. Significantly, the notion of 'trying your luck' raised an important point often missing in research on African youth and football related migration, which is that Ghanaian youth actively try to migrate through football despite the prevalence of risk. This is because football related migration is seen as a way of overcoming the uncertainty and constraints on life ambitions facing them in Ghana.

Due to the methodological approach used in this study, further research is needed before broader generalizations can be made. Nevertheless, the findings potentially have implications for policy makers and football administrators concerned with the migration of young African footballers. As noted by Jeffrey, when attempting to understand young people's agency 'it is important to ascertain the ways in which children and youth navigate plural intersecting structures of power' (2011, p. 2). Scholars, policy makers, and activists concerned with the migration of African footballers often lose sight of this point due to their focus on the practices of European clubs and to some extent fake scouts and agents. European clubs and unscrupulous agents undoubtedly do play a role in the migration process. Yet, as argued in this article it is important to also stay attentive to the agency of players and actors in African origin countries, particularly how the desire to migrate connects to conditions beyond the football industry. Policy responses that fail to acknowledge this point and focus solely on conditions in the football industry are likely to prove ineffective, because they will not be able to comprehend why and how youth are willing to take risks and 'try their luck' to migrate through football. 


\section{References}

Alegi P, 2010 African Soccerscapes: How a Continent Changed the World's Game (Hurst and Company, London)

Anderson B, 2007, "Motherhood, Apple Pie and Slavery: Reflections on Trafficking Debates". Centre on Migration, Policy and Society (COMPAS) Working Paper No. 48, University of Oxford. http://www.compas.ox.ac.uk/publications/Working\%20papers/Bridget\%20Anderson\%20WP0748.p df.

Armstrong G, Giulianotti R, 2004 Football in Africa (Palgrave Macmillan, UK)

Azzarito L, Harrison Jr L, 2008, "White men can't jump: race, gender and natural athleticism" International Review for the Sociology of Sport 43(4) 347-364

Bakewell O, De Haas H, 2007, "African migrations: continuities, discontinuities and recent transformations" in African Alternatives Eds Chabal P, Engel U, De Haan L (Brill, Leiden) pp 95-118

Bale J, Cronin M, 2003 Sport and postcolonialism (Bloomsbury Academic Publishing, London)

Beck U, 1992 Risk Society: Towards a New Modernity (Sage Publications, London)

Brown A, 2012, "Fabrice Muamba's collapse shows how prayer comes naturally to footballers" The Guardian. http://www.guardian.co.uk/commentisfree/andrewbrown/2012/mar/19/fabricemuamba-football-prayer-natural

Burfoot A, 1992, "White men can't run" Runner's World 27(8) 89-95

Burrell J, 2012 Invisible users: youth in the Internet cafés of urban Ghana (MIT Press, Cambridge, MA)

Carling J, 2002, "Migration in the age of involuntary immobility: theoretical reflections and Cape Verdean experiences" Journal of Ethnic and Migration Studies 28(1) 5-42

Carrington B, 1998, "Sport, masculinity and black cultural resistance" Journal of Sport and Social Issues 22(3) 275-298

Carrington B, McDonald I, 2001 Race, sport, and British society (Routledge, London)

Carter, T F, 2013. "Re-placing sport migrants: moving beyond the institutional structures informing international sport migration" International Review for the Sociology of Sport 48(1) 66-82 
Certeau, M. de, Translated by Rendell S, 2011 The Practice of Everyday Life (University of California Press, London)

Coe, A. and Wiser, J 2011. "Ghanaian footballers stranded in Mauritius". The Daily Guide Accra. www.modernghana.com/sports/343568/2/ghanaiansUfootballersU strandedUinUmauritius.html

Coe C, 2012, "Growing up and going abroad: how Ghanaian children imagine transnational migration" Journal of Ethnic and Migration Studies 38(6) 913-931

Darby P, 2013, "Moving players, traversing perspectives: global value chains, production networks and Ghanaian football labour migration" Geoforum 50 43-53

Darby P, Akindes G, Kirwin M, 2007, "Football academies and the migration of African football labor to Europe" Journal of Sport and Social Issues 31(2) 143-161

Darby P, Solberg E, 2010, "Differing trajectories: football development and patterns of player migration in South Africa and Ghana" Soccer and Society 11(1) 118-130.

Darkwah A. K, 2013, "Keeping hope alive: an Analysis of training opportunities for Ghanaian youth in the emerging oil and gas Industry". International Development Planning Review 35(2) 119-34

Donnelly P, Petherick L, 2004, "Workers' playtime? Child labour at the extremes of the sporting spectrum" Sport in Society 7(3) 301-321

Esson, J, 2013, "A body and a dream at a vital conjuncture: Ghanaian youth, uncertainty and the allure of football". Geoforum 47 84-92

Esson, J, 2015, "Better off at home? Rethinking responses to trafficked West African footballers in Europe" Journal of Ethnic and Migration Studies 41(3) 512-530

Ferguson J, 2006 Global shadows: Africa in the neoliberal world order (Duke University Press, Durham and London)

International Federation of Association Football, 2010, "Regulations on the Status and Transfer of Players" http://www.fifa.com/mm/document/affederation/administration/01/27/64/30/regulationsstatusa ndtransfer2010_e.pdf 
International Federation of Association Football, 2008, "Regulations of Players' Agents"

http://www.fifa.com/mm/document/affederation/administration/51/55/18/players_agents_regula tions_2008.pdf

Geschiere P, 1998, "Globalization and the power of indeterminate meaning: witchcraft and spirit cults in Africa and East Asia" Development and Change 29(4) 811-837

Giddens A, 1991 Modernity and self identity (Polity Press, Cambridge)

Harrison L, Azzarito Jnr L, Burden J, 2004, "Perceptions of athletic superiority: a view from the other side" Race Ethnicity and Education 7(2) 149-166

Hernández-Carretero M, Carling J, 2012 "Beyond 'kamikaze migrants': risk taking in West African boat migration to Europe" Human Organization 71(4) 407-416

Honwana A.M, de Boeck F, 2005 Makers and breakers: children and youth in postcolonial Africa (James Currey Publishers, Oxford)

Jeffrey C, 2011, "Geographies of children and youth II: global youth agency" Progress in Human Geography 35(4) 1-9

King C, 2004, "Race and cultural identity: playing the race game inside football" Leisure Studies 23(1) 19-30

Koser K, 2010, "Dimensions and dynamics of irregular migration" Population, Space and Place 16(3) 181193

Lanfranchi P, Taylor M, 2001 Moving with the ball (Berg Publishers, Oxford)

Langevang T, 2008, "We are managing! Uncertain paths to respectable adulthoods in Accra, Ghana" Geoforum 39 2039-2047

Langevang T, Gough K V, 2009, "Surviving through movement: the mobility of urban youth in Ghana" Social and Cultural Geography 10(7) 741-756

Langevang T, \& Gough K V, 2012, "Diverging pathways: young female employment and entrepreneurship in sub-Saharan Africa". The Geographical Journal 178(3) 242-252.

McCarthy D, Jones R L, Potrac P, 2003, "Constructing images and interpreting realities: the case of the black soccer player on television" International Review for the sociology of Sport 38(2) 217-238 
Messner M A, 1989, "Masculinities and athletic careers" Gender and Society 3(1) 71-88

Messner M.A, Dunbar M, Hunt, D, 2000, "The televised sports manhood formula" Journal of Sport and Social Issues 24(4) 380-394

Meyer B, 1998, "Commodities and the power of prayer: Pentecostalist attitudes towards consumption in contemporary Ghana" Development and Change 29(4) 751-776

Nayak A, 2006, "After race: ethnography, race and post-race theory" Ethnic and Racial Studies 29(3) 411430

Nayak A, 2010, "Race, affect, and emotion: young people, racism, and graffiti in the postcolonial English suburbs" Environment and Planning A 42(10) 2370-2392

Nyamnjoh F B, 2013, "Fiction and reality of mobility in Africa" Citizenship Studies 17(6-7) 653-680 DOI:10.1080/13621025.2013.834121

Nyamnjoh F B, \& Page B, 2002, "Whiteman Kontri and the enduring allure of modernity among Cameroonian youth" African Affairs 101(405) 607-634

Obeng-Odoom F, 2013 Governance for pro-Poor Urban Development: Lessons from Ghana (Routledge, London)

Parish J, 2000, "From the body to the wallet: conceptualizing Akan witchcraft at home and abroad" Journal of the Royal Anthropological Institute 6(3) 487-500

Pieterse E, 2011. "Grasping the unknowable: coming to grips with African urbanisms" Social Dynamics $37(1) 5-23$

Poli R, 2010a, "African migrants in Asian and European football: hopes and realities" Sport in Society 13(6) 1001-1011.

Poli R, 2010b, "The migrations of African football players to Europe: human trafficking and neo-colonialism in question" at Football for Development in Vienna, Austria 23/04/2010. http://www.footballfordevelopment.net/uploads/tx_drblob/storage/Poli_migration-of-Africanfootball-players_01.pdf

Schatzberg M.G., 2006, "Soccer, science, and sorcery: causation and African football" Afrika Spectrum 41(3) 351-369 
St Louis B, 2004, "Sport and common sense racial science" Leisure Studies 23(1) 13-46

Swanton D, 2010, "Sorting bodies: race, affect, and everyday multiculture in a Mill Town in Northern England" Environment and Planning A 42 (10) 2332-2350

Ungruhe C, 2010, "Symbols of success: youth, peer pressure and the role of adulthood among juvenile male return migrants in Ghana" Childhood 17(2) 259-271

Van Blerk L, 2013, "New street geographies: the impact of urban governance on the mobilities of Cape Town's street youth" Urban studies 50(3) 556-573

Van der Meij N, Darby P, 2014, "No one would burden the sea and then never get any benefit: Family involvement in players' migration to football academies in Ghana", in Football and Migration: Perspectives, Places, Players Eds Elliott R, Harris J (Routledge, New York \& London) pp 157-159

Vigh H, 2009, "Motion squared: a second look at the concept of social navigation" Anthropological Theory 9(4) 419-438

Waage T, 2006, "Coping with unpredictability: preparing for life in Ngaoundere, Cameroon", in Navigating Youth, Generating Adulthood: Social Becoming in an African Context Eds Christiansen C, Vigh H, Utas M (Nordiska Afrika institute) pp 61-87 